\title{
EVALUATION OF THE DIRAMIC SYSTEM FOR URINE CULTURES
}

\author{
Cristian Kendi Higuchii ${ }^{1}$; Carlos Roberto Corrêa² ${ }^{2}$ Vera Lucia Mores Rall ${ }^{1}$; Ary Fernandes Junior ${ }^{1 *}$
}

\begin{abstract}
${ }^{1}$ Departamento de Microbiologia e Imunologia, Instituto de Biociências, Universidade Estadual Paulista Julio de Mesquita Filho, Botucatu, SP, Brasil; ${ }^{2}$ Laboratório de Análises Clinicas, Setor de Microbiologia, Faculdade de Medicina Universidade Estadual Paulista Julio de Mesquita Filho, Botucatu, SP, Brasil
\end{abstract}

Submitted: July 01, 2005; Approved: March 26, 2006

\begin{abstract}
The use of the Diramic system in microbiological diagnosis of urinary tract infections (UTI) was evaluated. This system was developed at the National Center for Scientific Research of Cuba, and it reads turbidimetric changes of microbial growth in culture media at $37^{\circ} \mathrm{C}$ incubated for 4 hours. A total of 396 urine specimens were tested in the Laboratory of Microbiology of the School of Medicine - UNESP, Brazil using the Diramic system and the counting of colony forming units per urine millimeter (calibrated loop) as the reference method. The coincidence rate between the two methods was $96.46 \%$ (382 urine samples), and the differences in results were not significant ( $\mathrm{p} \leq 0.05$ ). Sensitivity and specificity rates were $84.37 \%$ and $98.80 \%$, respectively. False negative and false positive rates were $2.50 \%$ and $1.01 \%$, respectively. The microorganisms isolated from positive urines were: Escherichia coli (68.75\%); Klebsiella pneumoniae (10.94\%); yeast (6.25\%); Pseudomonas aeruginosa (4.69\%); Enterobacter cloacae (3.12\%); Proteus mirabilis, coagulase negative Staphylococcus, Morganella morganii, and Citrobacter freundii (1.56\% each). The Diramic system was effective as screening method for urine cultures, however restrictions in the UTI diagnosis caused by yeasts and patients undergoing antibiotic therapy were negative characteristics of the system.
\end{abstract}

Key words: Diramic, calibrated loop, urinary tract infection, urine cultures

\section{INTRODUCTION}

The urinary tract infection (UTI) is an important health problem affecting millions of people every year, and women are especially prone to it (8). This type of infection can be classified as upper UTI (kidneys and ureters) and lower UTI (uretra and bladder). Nearly all UTIs are caused by bacteria that enter the urethral opening and move upwards to the urinary bladder and sometimes to the kidneys. Significant bacteriuria occurs when there are $10^{5}$ colony forming units $/ \mathrm{mL}$ $(\mathrm{CFU} / \mathrm{mL})$ in a properly collected urine (7) and since 1960 the calibrated loop method has come into general use for determining CFU in urine (2). UTI represents the major parcel among all types of infections, and urine is the specimen most commonly (25\%) submitted to microbiology laboratories that work mainly with samples proceeding from hospitals
$(6,11,13,16)$. However, a high percentage of negative results (70-80\%) is frequent $(1,3,4,14)$. Bacterial infections in the lower urinary tract (bladder and urethra) are very common and Escherichia coli is the most common organism present (80\%) in UTI, although other enteric organisms such as Klebsiella sp. and enterococci, as well as staphylococci, have also been identified $(9,14)$.

Nowadays, clinicians are challenged to order clinically relevant, low-cost, effective laboratory tests and antibiotic therapy. Together, physicians and laboratories must have guidelines and strategies that provide high quality treatment for the patient, while minimizing costs and preventing further emergence of antimicrobial drug resistance (10). Thus, the National Center for Scientific Research, Cuba, developed the Diramic system (Diagnóstico Rápido Microbiológico), a semiautomatic equipment designed for the determination of

*Corresponding Author. Mailing address: Departamento de Microbiologia e Imunologia, Instituto de Biociências, UNESP. 18618-000, Botucatu, SP, Brasil. Tel.: (+5514) 3811-6058, Fax: (+5514) 3815-3744. E-mail: ary@ibb.unesp.br 
urinary infections. The measuring unit is a turbidimetric reader, calibrated with the Mc Farland turbidity standards. Turbidimetric changes due to microbial growth in the culture media in four hours can be detected by optical transmittance. Identification of $E$. coli and the corresponding antibiogram are also possible (15). The small volumes of culture medium used in the system and the short period of time necessary for detection make the system a rapid and economical method for screening UTI (15). This study reports the results of the evaluation of the Diramic system by comparing results with those obtained using a reference method -calibrated loop (CL) or colony forming units per milliliters $(\mathrm{CFU} / \mathrm{mL})$. The frequency of microorganisms involved in the UTI is also reported.

\section{MATERIALS AND METHODS}

\section{Urine specimens}

A total of 396 urine specimens from inpatients of the Hospital of the School of Medicine, São Paulo State University (UNESP), Botucatu, São Paulo, Brazil, during the year of 2001, were collected and processed by the Diramic System and by the reference method of calibrated loop (CL).

\section{Diramic system}

The Diramic system was calibrated using fresh culture media. For urine analysis, the method described in the use manual (5) was used. $250 \mu \mathrm{L}$ of urine were inoculated into vials with $2.2 \mathrm{~mL}$ of culture medium and a turbidimetric reading was carried out at hour zero. The vials were incubated at $37^{\circ} \mathrm{C}$ during four hours, when a second reading was carried out in order to detect positive specimens by the increased turbidity in the cultures. Fig. 1 shows the Diramic system equipment.

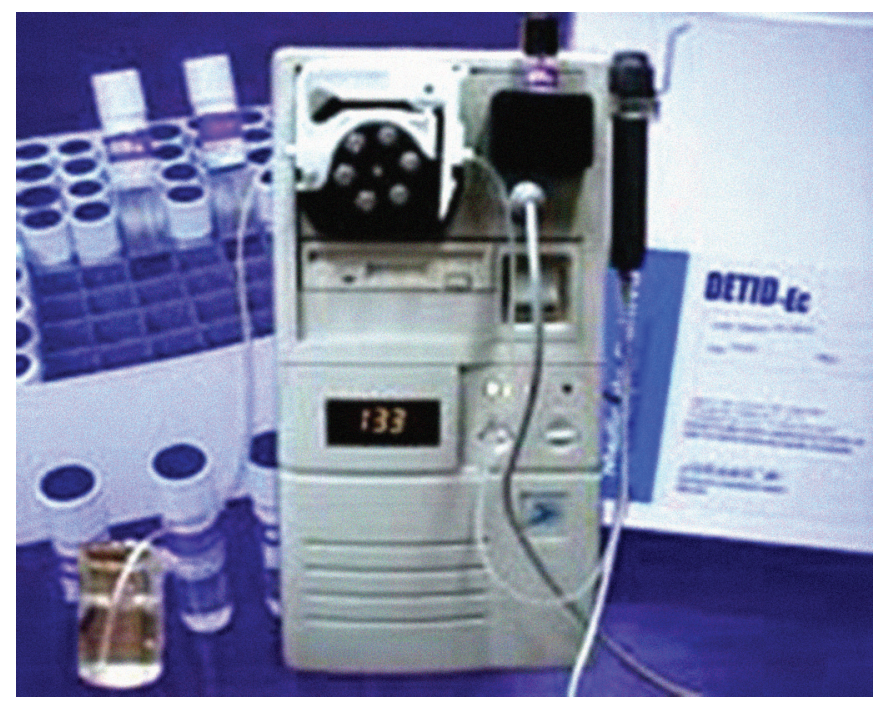

Figure 1. The Diramic System.

\section{Calibrated loop (CL)}

Urine $(10 \mu \mathrm{L})$ was plated on Sheep Blood Agar and Cled/ MacConkey Medium and incubated at $37^{\circ} \mathrm{C}$ for $18 \mathrm{~h}$. Those cultures presenting $\mathrm{CFU} / \mathrm{mL} \leq 10^{4}$ were considered positive and the identification of the isolates was performed (12).

\section{Statistical analysis}

The comparison between the methods was made by the non-parametric method (McNemar test) and the Yule coefficient, considering $5 \%$ of significance. The Sensitivity and specificity percentages were calculated as follows:

$$
\begin{aligned}
& \% \text { Sensitivity }=\frac{\text { True positives }}{\text { True positives }+ \text { False negatives }} \times 100 \\
& \% \text { Sensitivity }=\frac{\text { True negatives }}{\text { True negatives }+ \text { False positives }} \times 100
\end{aligned}
$$

\section{RESULTS}

The results are shown in Tables 1 and 2, and the isolated microorganisms using the reference method are shown in Table 3. In the Diramic system evaluation, 382 results (54 true positive

Table 1. Results of urine cultures obtained using the Diramic system and the calibrated loop (CL) reference method.

\begin{tabular}{ccccc}
\hline Urine cultures & \multicolumn{2}{c}{ Diramic system } & \multicolumn{2}{c}{$\begin{array}{c}\text { Reference } \\
\text { method (CL) }\end{array}$} \\
\hline Positive & $\mathrm{n}$ & $(\%)$ & $\mathrm{n}$ & $(\%)$ \\
Negative & 58 & 14.6 & 64 & 16.1 \\
Total & 338 & 85.3 & 332 & 83.8 \\
\hline
\end{tabular}

$\left(\mathrm{X}^{2}=1.786, \mathrm{p}=0.1815\right.$; and $\left.\mathrm{Y}=99.55 \%\right)$.

Table 2. Comparison of results of urine cultures obtained using the Diramic system and the calibrated loop (CL) reference method.

\begin{tabular}{crr}
\hline & Urine specimens & $\%$ \\
\hline Coincident rate & 382 & 96.46 \\
Coincident positive rate & 54 & 84.37 \\
Coincident negative rate & 328 & 98.80 \\
False positive rate & 4 & 1.01 \\
False negative rate & 10 & 2.52 \\
Sensitivity & & 84.37 \\
Specificity & \multicolumn{2}{c}{98.80} \\
\hline
\end{tabular}


and 328 true negative) were coincident with those obtained by the reference method. Four false positive and ten false negative results were obtained, resulting in sensitivity and specificity of $84.37 \%$ and $98.80 \%$, respectively. Escherichia coli species was the main $(68.75 \%)$ species isolated from positive urine cultures.

Table 3. Microorganisms isolated from the 64 positive urine cultures using the calibrated loop (CL) reference method.

\begin{tabular}{lc}
\hline \multicolumn{1}{c}{ Microorganism } & Isolates (\%) \\
\hline Escherichia coli & $44(68.75)$ \\
Klebsiella pneumoniae & $7(10.94)$ \\
Yeast & $4(6.25)$ \\
Pseudomonas aeruginosa & $3(4.69)$ \\
Enterobacter cloacae & $2(3.12)$ \\
Coagulase negative Staphyloccocus & $1(1.56)$ \\
Proteus mirabilis & $1(1.56)$ \\
Morganella morganii & $1(1.56)$ \\
Citrobacter freundii & $1(1.56)$ \\
\hline Total & $64(100)$ \\
\hline
\end{tabular}

\section{DISCUSSION}

The non-parametric test of MacNemar $\left(X^{2}=1.786\right.$ and $\mathrm{p}=0.1815)$ and the Yule coefficient $(\mathrm{Y}=99.55 \%)$ indicated that there were no differences between the results obtained by the two methods. The negative urine specimens rate (85.3\%) using the reference method (CL) was slightly higher than the one obtained in previous studies $(3,4,14,15)$. The reason for this increase in negative results may be that these cultures were unnecessarily requested by medicine graduate students and residents. The specificity $(98.80 \%)$ was higher than the value (94.49\%) reported by Ruiz et al. (2004). The high specificity, the small volume of culture medium required for the test and the short period of time necessary for the analysis make this system a valuable alternative as a screening method in any clinical microbiology laboratory.

The ten false negative results in the Diramic system corresponded to four urines containing $E$. coli, three yeasts, one coagulase negative Staphylococcus, one Pseudomonas aeruginosa and one Klebsiella pneumoniae. Two E. coli and $P$. aeruginosa strains were isolated from urine of patients that had already initiated antibiotic therapy, suggesting that the presence of antibiotic was responsible for the absence of growth or low multiplication bacteria. In addition, Mueller Hinton medium was not adjusted for yeast growth in 4 hours. Therefore, six out of ten false negative results were elucidated and the others four remain unknown, and could be attributed to human or the Diramic system errors.
We concluded that it is convenient to use Diramic system in urine cultures due to technical and economical aspects. However, it is important to rigorously control the exams requests and the testing of urine cultures when the etiologic agent is suspected to be yeast and/or the urine is from patients in antibiotic therapy process.

\section{ACKNOWLEDGEMENTS}

We thank the Laboratório de Microbiologia do Hospital das Clínicas da Faculdade de Medicina/Universidade Estadual Paulista Julio de Mesquita Filho/UNESP/Campus de Botucatu for the urine cultures and Cepa Biotecnologia Ltda for Diramic system kits.

\section{RESUMO}

\section{Avaliação do sistema Diramic para urinoculturas}

O sistema Diramic foi avaliado para o diagnóstico das infecções do trato urinário (ITU). O sistema Diramic foi desenvolvido em Cuba e possibilita resultados de diagnóstico das infecções do trato urinário (ITU) em quatro horas e baseiase na variação da turvação do crescimento microbiano no meio de cultura após incubação a $37^{\circ} \mathrm{C} / 4$ horas. 396 amostras de urinas provenientes de ambulatórios e enfermarias do HC da FMBUNESP-Botucatu/SP foram analisadas pelo sistema Diramic. O método da alça calibrada (AC) foi adotado como método de referência. A taxa de coincidência entre os dois métodos foi de 96,46\% (382 amostras de urina), não havendo diferença significativa entre os resultados obtidos nos dois métodos. Os resultados para sensibilidade e especificidade foram 84,37 e $98,80 \%$ respectivamente e 10 resultados no Diramic foram falsos negativos (2,5\%) e 4 falso positivos (1,01\%). Os microrganismos identificados nas urinas positivas foram Escherichia coli $(68,75 \%)$, Klebsiella pneumoniae $(10,94 \%)$, leveduras $(6,25 \%)$, Pseudomonas aeruginosa (4,69\%), Enterobacter cloacae $(3,12 \%)$ e Proteus mirabilis, Staphyloccocus coagulase negativo, Morganella morganii e Citrobacter freundii também foram identificadas ( $1,56 \%$ para cada espécie). O método Diramic foi eficiente na triagem das urinoculturas, porém verificou-se algumas restrições quanto ao diagnóstico das infecções do trato urinário quando causadas por leveduras e em pacientes submetidos a antibioticoterapia.

Palavras-chave: sistema Diramic, alça calibrada, ITU, urinoculturas

\section{REFERENCES}

1. Alarcón, R.C.; Ruiz, F.T.; Tamayo, A.Z.; Carmona, G.R.; Varela E.A.; Ochoa, G.T.; Frómeta, N.R. Mycrob-1000: Una alternativa para la determinación rápida del urocultivo en el nivel primario de salud. Rev. Cubana. Med. Trop., 56, 135-138, 2004. 
2. Albers, A.C.; Fletcher, R.D. Accuracy of Calibrated-Loop Transfer. J. Clin. Microbiol., 18, 40-42, 1983.

3. Colombrita, D.; Ravizzola, G.; Pirali, F.; Manni, M.; Manca, N.; Savoldi, E.; Turano, A. Evaluation of BACTEC system for urine culture screening. J. Clin. Microbiol., 27, 118-119, 1989.

4. Dias, C.A.G.; Mezzari, A.; Cauduro, P.F.; Koch, E.; Hemb, R. Avaliação da coloração de Gram e filtração colorimétrica na triagem de uroculturas. Rev. Brás. Patol. Clín., 29, 80-82,1993.

5. Diramic Manual do Usuário 1997. Versão de software: 4.0. Rev. 04/ 97. Cepa Biotecnologia, Belo Horizonte: 1992-1997.

6. Escande, M.C.; Richet, H. Gram stain of uncentrifuged urine for rapid detection of leukocysturia. Eur. J. Clin. Microbiol., 5, 668669, 1986.

7. Kass, E.H. Bacteriuria and the diagnosis of infection of urinary tract. Arch. Intern. Med., 100, 709-714, 1956.

8. Leigh, D. Urinary-tract infections. In: Topley, W.W.C.; Wilson, G.S. Principles of bacteriology, virology and immunity, $8^{\circ}$ ed., Edward Arnold, London: v.3.11, 1990, p.197-213.

9. Lerner, G.R. Urinary tract infections in children. Pediatr. Ann., 23, 463-473, 1994.
10. Lo, T.S.; Smego, R.A. Avoiding laboratory pitfalls in infectious diseases. Postgraduate Med. J., 80, 660-662, 2004.

11. Madan, E.; Quinter, H.; Blackwell, J. Urine screening: an alternative to urine cultures Ann. Clin. Lab. Sci., 18, 116-119, 1988.

12. Mahon, C.R.; Manuselis, J.R.G. Textbook of diagnostic microbiology, W.B. Saunders Companhy, Philadelphia, 1995, 1134pp.

13. Muray, P.R.; Traynor, P.; Hopson, D. Evaluation of microbiological processing urine speciment: comparison of overnight versus twoday incubation. J. Clin. Microbiol., 30, 600-601, 1992.

14. Rosa, T.T.; Vasconcelos, D.; Castro, L.C.G.; Rangel, E.B.; Néri, F.A.A.L. Perfil microbiológico e sensibilidade a antimicrobianos de uroculturas realizadas no Hospital Universitário de Brasília, 1990 á 1992. Rev. Brás. Méd., 33, 14-19, 1996.

15. Ruiz, F.T.; Carmona, G.R.; Penabad, C.R.; Alarcón, R.C. Evaluation of Diramic system for detection of urinary tract infections and for Escherichia coli identification. Rev. Latiam. Microbiol., 46, 67-71, 2004.

16. Thomaz, J.G. Urinary Tract Infections. In: Mahon, C.R.; Manuselis, G.J. Textbook of Diagnostic Microbiology. W.B. Saunders Company, Philadelphia, 1995, p.948-969. 